\title{
From allozymes to NGS: population genetics of forest trees in Slovakia in the past 40 years
}

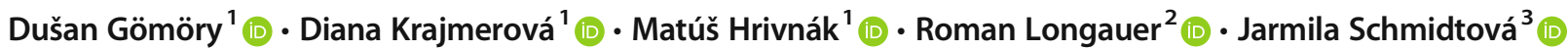

Received: 14 December 2020 / Accepted: 9 February 2021 / Published online: 12 March 2021

(C) Plant Science and Biodiversity Centre, Slovak Academy of Sciences 2021

\begin{abstract}
This review summarizes the development of population genetics and population genomics studies of forest trees in Slovakia during the past 40 years. Various protein and DNA markers have been applied during this period to address several topics in evolutionary genetics and biogeography of trees: allozymes, uniparentally inherited chloroplast and mitochondrial markers, simple sequence repeats and single nucleotide polymorphisms. The main object of studies of phylogeny and postglacial migration were Fagus sylvatica s.l. and eastern-Mediterranean firs (Abies Mill. section Abies), where the divergence of genetic lineages (species and subspecific taxa) in time, as well as colonization of the current ranges during the Holocene were reconstructed. The studies on intraspecific gene flow and homoploid hybridization focused on hybrid swarms Pinus sylvestris/P. mugo and firs. Unusual maternal inheritance of chloroplast DNA was revealed in P. mugo $\times$ P. sylvestris crosses. Contrasting geographical structures of hybrid zones were revealed in wind-dispersed vs. animal-dispersed trees. Within the studies of adaptation, signals of selection were identified both in field observations and common-garden experiments on Picea abies, F. sylvatica and A. alba. Perspectives of ongoing research employing next-generation sequencing were shortly outlined.
\end{abstract}

Keywords Allozymes $\cdot$ Forest trees $\cdot$ Maternally inherited markers $\cdot$ Microsatellites $\cdot$ Next-generation sequencing $\cdot$ Sanger sequencing

\section{Introduction}

The heritable basis of intraspecific and interspecific variation of forest trees has been of interest far long before the first tools appeared, allowing to study it explicitly. In contrast to other wild-growing plants, the existence of genetic variation has direct economical implications in trees. At the advent of the modern forestry, associated with extensive planting of forests, seeds and plants were procured from the most easily accessible sources and transferred across species' ranges without

Special issue Progress in Slovak Botany

Dušan Gömöry

gomory@tuzvo.sk

1 Faculty of Forestry, Technical University in Zvolen, TG Masaryka 24, 96001 Zvolen, Slovakia

2 National Forestry Centre, Forestry Research Institute, TG Masaryka 22, 96001 Zvolen, Slovakia

3 Faculty of Wood Technology, Technical University in Zvolen, TG Masaryka 24, 96001 Zvolen, Slovakia limitation. This approach frequently led to economical disaster for forest owners in terms of huge losses on timber production and other benefits from forests. Therefore, field experiments such as common gardens have rapidly become a tool guiding the choice of seed sources and transfers of forest reproductive materials. The first field trial testing populations of various origins (provenances) of Scots pine (Pinus sylvestris L.) collected across Europe was established already in 1745 by French navy officer Duhamel du Monceau (Langlet 1971) and was followed by similar experiments, aiming at the selection of seed sources for reforestation. Of course, for a forester, the main selection criterion is yield rather than Darwinian fitness (König 2005); however, if a newly established forest stand survives until the rotation age (typically more than 100 years) and produces a high volume of biomass, it can be regarded as a sign that it is site-adapted. International coordination of provenance research was also among the prominent motivations for establishing the International Union of Forestry Research Organizations (IUFRO) in 1892 (Seppälä 1998). At the territory of the present-day Slovakia, IUFROcoordinated provenance experiments were established as early as in 1909 (Konôpka et al. 2013). Since then, a plenty of 
national as well as international provenance trials and progeny tests with practically all commercially important tree species have been established in Slovakia.

The problem of common-garden experiments is that the commonly assessed phenotypic traits are typically complex, polygenic, and are affected by the environment, which cannot be fully controlled in field experiments; therefore, they cannot be used to detect genetic variation at the genic level. With the development of the methods of electrophoretic separation of proteins, analysis of allelic variants at genes controlling the synthesis of enzymes (isoenzymes/isozymes/allozymes) became the first widespread tool (Feret and Bergmann 1976), and allozyme markers were considered a standard for population genetic studies in forest trees until the late 1990s. Even though the potential of the analysis of the hereditary material itself was recognized quite early (Hall et al. 1976), the use of DNA-based markers in forest trees quickly expanded only after polymerase chain reaction (PCR) has become widely available.

In Slovakia (more exactly, Czechoslovakia), the boom of marker studies was seized quite early: the first isozyme lab dealing with trees was established at the Institute of Dendrobiology of the Slovak Academy of Sciences in Mlyňany in mid-1980s, (later moved to Institute of Plant Genetics and Biotechnology in Nitra), and with a small delay, another lab at the University of Forestry and Wood Technology in Zvolen (today Technical University in Zvolen) followed. At the Forestry Research Institute in Zvolen, a separate research group was established, although technically dependent on the university lab. Later, allozymes have become gradually replaced by various types of DNA markers.

Due to their longevity, slow generation turnover and huge dimensions at adult age, forest trees have never been favourite models for the studies of fundamental phenomena in genetics. The overwhelming majority of the studies in forest trees used genetic tools to address the same issues as the botanists usually do: evolutionary and migration history of species, adaptation to environment, gene flow and hybridization etc. The progress in 'population genetics of forest trees' since the appearance of genetic markers has in fact been identical with progress in botany, not only in Slovakia but also elsewhere in the world.

The aim of this review is summarizing (by far not exhaustively) the most important outcomes of studies employing various types of genetic markers in forest trees in Slovakia, not necessarily based only on local biological materials.

\section{Descriptive studies}

Like in other cases of exploration of an unknown terrain, marker studies started with the description of variation patterns and assessment of variation levels. The very first allozyme study coming from Slovakia was that of Kormuták (1981) on isozyme variation in Abies species. Firs, and especially silver fir (Abies alba Mill.) remained the main object of interest during this initial stage (Kormuták et al. 1982, 1993; Matúšová 1995; Ziegenhagen et al. 1996). These studies were largely restricted to the assessment of variation levels, and their very local geographical scale did not allow any deeper insights into the evolutionary context, even when such attempts were sometimes made.

In Zvolen, in accordance with the university profile, initial studies were more focused on forestry-relevant issues such as the effects of management on genetic structures of forest stands or seed orchard crops, again mainly on a local scale. A study in Norway spruce (Picea abies Karst.) revealed that old-growth stands and naturally regenerated managed stands showed similar genetic variation levels, while stands originating from reforestation were less genetically diverse and strongly but randomly differentiated, probably due to small effective population sizes of seed sources and the resulting genetic drift (Gömöry 1992). Studies in seed orchards revealed contrasting self-fertilization rates and levels of genetic contamination of seed crop by background pollen in European larch (Larix decidua Mill.) and Scots pine, resulting from different properties of pollen grains (different size and the absence of air sacks in larch; Paule and Gömöry 1992). The issue of seed orchard management was later revisited: effective population sizes of seed orchards of Pinus sp. were assessed based on male and female flowering intensity and flowering phenology, and the effects of management measures on the genetic structures of their crops were assessed using allozyme markers (Gömöry et al. 2003; Machanská et al. 2013).

\section{Phylogeny and postglacial migration}

For the research group in Zvolen, beech taxa in western Eurasia (Fagus sylvatica L. sensu lato) have been a favourite object of interest since the early 1990s, when a large-scale monitoring of genetic variation of this species started in cooperation with University of Bordeaux, France. Through international collaboration and own collections, a set of 280 population samples covering the eastern half of the distribution of F. sylvatica subsp. sylvatica (European beech) and the whole range of $F$. sylvatica subsp. orientalis (eastern or oriental beech) was assembled and analyzed by allozyme markers. The resulting studies revealed that oriental beech is incomparably more differentiated and more diverse than European beech and is composed of three geographically separated genetic lineages, distributed in the Alborz Mts. in Iran, the Caucasus and the Asia Minor (extending to eastern Greece and Bulgaria), European beech being genetically most 
proximate to the Turkish lineage. A substantially higher allelic richness in oriental beech is an indication that the Pleistocene glaciations affected its gene pool less severely than European beech (Gömöry et al. 2007; Gömöry and Paule 2010). On the other hand, climatic fluctuations during the Pliocene and the Pleistocene caused expansions and retreats of distribution ranges, accompanied by contacts and hybridization between regional genetic lineages; the most prominent example is beech in Crimea, sometimes considered a separate taxon F. taurica Popl. Subsequent development of mathematical and informatics tools allowed explicit testing of phylogenetic scenarios for this taxonomical complex by Approximate Bayesian Computation (ABC). The best-supported scenario placed the splits of genetic lineages of oriental beech into the Early Pleistocene (1.62-1.87 My), while the clade leading to European beech diverged from the Turkish lineage at 1.18 My. The hybrid origin of Crimean beech from the hybridization between the Caucasian and the European lineage was confirmed, the timing of this event being $144 \mathrm{ky}$ (Late Pleistocene). On the other hand, another suspected hybrid lineage, the Balkan beech (treated as separate taxon F. moesiaca Czeczott by local botanists) is just a separate clade diverged from the Turkish lineage during the Cromer interglacial (817 ky), and the current European beech occupying a major part of Europe split from the Balkan lineage at the beginning of the Weichsel/Würm glacial (96 ky) (Gömöry et al. 2018).

When at the beginning of 2000s, the 5th FP EU project Fossilva was organized, aiming at the reconstruction of Holocene migration of main European tree species based on the combination of paleobotanical and genetic methods, the $F$. sylvatica allozyme dataset, along with a similar dataset on A. alba gathered at the Forestry Research Institute, Zvolen, were included in the analyses. In contrast with earlier assumptions, both types of data showed that the principal glacial refugia, from which the major part of distribution ranges of temperate tree species were colonized, were not located in the very southern parts of the main European southern peninsulas (Balkans, Apennine and Iberian) but farther in the North. In the case of beech, the main refugium was situated at the eastern foothills of the Alps, from where beech migrated to almost the whole current range. The spread from refugia in Italy and southern Balkans was blocked by large river valleys (Po, Danube). The refugia at the French Mediterranean coast started to expand too late (6-7 ky), the surrounding areas were already colonized by the Slovenian/Istrian genetic lineage. Finally, the refugia in the Cantabrian mountains (documented by macrofossils, pollen record as well as allozyme data) did not expand at all, their population sizes were probably too small and the resulting genetic drift may have depleted their gene pools of adaptively important alleles; they were overlaid by newcomers from the main refugium (Magri et al. 2006).

The migration history of silver fir is partly different. Principal refugia contributing to the colonization of the current range were located in northern Apennines and southern Balkans; allozyme data suggest a third important refugium in northwestern Balkans, but this is not sufficiently documented by the fossil record (Liepelt et al. 2009). Maternally inherited mitochondrial markers allowed tracing the migration trails quite in detail: the Pannonian lowland forms a large gap in the distribution of fir, the contact zone east of this gap (the Carpathians) was found to be very short $(\sim 70 \mathrm{~km})$ and mixed-haplotype populations are found only in the close proximity of the boundary between mitochondrial lineages. On the other hand, the boundary in the West (the Dinarians) is long and complicated, when the Balkan lineage migrated along the coast even up to northeastern Italy, while the Central-European lineage colonized the interior until eastern Bosnia (Gömöry et al. 2004). Origin from different refugia has also practical implications: dendrochronological analyses documented that genetic lineages differ in growth patterns, resulting from different sensitivity to climate and industrial pollution (Bošel'a et al. 2016).

In the genus Abies, species richness in the Mediterranean area is especially high in the eastern part. There is, however, no unanimity about taxonomical treatment of local populations. The species status of A. nordmanniana (Steven) Spach and A. cilicica (Antoine \& Kotschy) Carr. is undisputed, while A. equi-trojani Asch. et Sint. ex Boiss. and A. bornmuelleriana Mattf. are considered separate species by local botanists but later revised as subspecies of A. nordmanniana by Coode and Cullen (1965). Phylogeny of this complex was studied by Hrivnák et al. (2017) using nuclear microsatellites (eastern lineage of A. alba Mill. and A. cephalonica Loud. were included for comparison). $\mathrm{ABC}$ simulations showed that $A$. alba and A. nordmanniana diverged from the common ancestor $3.73 \mathrm{My} \mathrm{BP.}$ A. bornmuelleriana split from the southern A. nordmanniana lineage $3.08 \mathrm{My} \mathrm{BP,} \mathrm{i.e.,} \mathrm{both} \mathrm{events} \mathrm{occurred} \mathrm{still} \mathrm{in} \mathrm{the}$ Pliocene. In A. nordmanniana, two genetic lineages were revealed (cryptic subspecies), separated by the ridge of the Grand Caucasus, which diverged 692 ky BP. Finally, A. equi-trojani appeared 621 ky BP, i.e., in the Early Pleistocene. Divergence times indicate that $A$. bornmuelleriana would deserve species rather than subspecies status. Meanwhile the two subspecies of A. cilicica showed a level of genetic differentiation even higher than for the other studied species - on the other hand, ABC simulations showed divergence of the two subspecies at 695 ky BP, conforming to the level of subspecies in this study.

On a genus-wide scale, phylogeny of Abies was addressed in a PCR-RFLP study of chloroplast DNA by Kormuták et al. (2004), covering 15 Asian, 6 North-American and 7 Mediterranean species. The analysis revealed a strong divergence of the Mediterranean group from the rest, differentiation within the North-American group (especially between sections Balsameae and Grandes), and less variation among the Asian firs, with the exception of $A$. mariesii Mast.

A peculiar studied species was Picea omorika (Panč.) Purk, which is a narrow endemic of deep river valleys in Serbia and 
Bosnia and Herzegovina. In spite of a minuscule range, two genetic lineages were found within the Bosnian populations (Ballian et al. 2006). A chaotic pattern of genetic differentiation a low allelic richness are indication of a strong genetic drift in this Tertiary relic, which occupied a large part of Europe during the Pleistocene (Ravazzi 2002), but as a species adapted to cold and moist climate, it remained trapped in favourable sites within the refugial area and was not able to spread across the Balkans with generally warm and summerdry climate.

\section{Gene flow and hybridization}

Hybridization has always been a high-priority topic for the research team in Mlyňany/Nitra. The initial object of interest was the genus Abies, where pioneering work has been done in artificial hybridization, profiting from rich resources of the Arboretum Mlyňany (Kormuták 1985, 2004; Kormuták et al. 2008b, 2013). Cytological aspects of interspecific hybridization in firs were studied as well (Kormuták 1986; Kormuták et al. 2002). Genetic markers (allozymes, PCRRFLP cpDNA) were initially used just to verify the hybrid status of the offspring (Kormuták et al. 1992, 1993) and to confirm paternal inheritance of plastids (Salaj et al. 1998). Later, the focus shifted to natural hybridization of pines, mainly the studies of hybrid swarms of $P$. sylvestris L. and P. mugo Turra. Again, PCR-RFLP cpDNA markers were initially used for validation of hybrid status and quantification of hybrid seeds in open-pollinated progenies collected in nature (Kormut'ák et al. 2005, 2008a; Maňka et al. 2015). However, development and verification of species-specific cpDNA markers combined with nuclear markers and morphometry allowed assessing the degree and direction of introgression and revealed maternal inheritance of plastid DNA in P. mugo $\times$ P. sylvestris crosses, which is exceptional in the Pinaceae (Kormuták et al. 2017, 2018, 2020).

Another species-rich taxon characterized by high levels of interspecific gene flow is oaks. In Slovakia, the species of Quercus L. subg. Lepidobalanus (Endl.) Oerst. share substantial parts of their genomes. A combination of morphometry and allozyme analysis in mixed populations showed that even individuals unambiguously classified as $Q$. robur $\mathrm{L}$. based on morphological traits may contain up to $90 \%$ of genes typical for $Q$. petraea (Matt.) Liebl. and vice versa; to a lesser extent, this is true also for $Q$. pubescens Willd. (Gömöry and Schmidtová 2007). Whether this is a result of sharing ancestral polymorphisms or recent gene flow is still a matter of controversy (Muir and Schlötterer 2005 vs. Lexer et al. 2006). Anyway, not all portions of the genome show identical levels of interspecific differentiation: while in most allozyme genes, the differentiation is very small, the gene for glucose dehydrogenase exhibited coefficient of differentiation of 0.47 . Taking into account contrasting ecological requirement of sessile vs. pedunculate oak, such skewed distribution of the coefficient of differentiation suggests that the gene in question may either be under selection pressure itself or be linked to adaptively significant genes (Gömöry et al. 2001).

Genetic architecture of hybrid zones is another topic associated with gene exchange between differentiated genetic lineages. As stated above, there is a plenty of contact lines between ranges of different but interfertile species or intraspecific genetic lineages originating for instance from different refugia. One of them is the contact zone of $A$. alba and A. cephalonica in southern Balkans, forming a hybrid taxon A. borisii-regis Mattf. Krajmerová et al. (2016) studied this zone employing a combination of a maternally inherited mitochondrial marker and nuclear microsatellites. The distribution of maternal lineages (reflecting colonization by seed dispersal) showed a sharp boundary between the A. alba and A. cephalonica lineages around $39.10^{\circ} \mathrm{N}$, while the latitudinal cline is very steep (width of $0.20^{\circ} \approx 22 \mathrm{~km}$ ). In contrast, distribution of nuclear gene pools (reflecting gene flow by pollen) suggests a broad introgression zone with a centre at $40.14^{\circ} \mathrm{N}$ and width of $2.32^{\circ} \approx 255 \mathrm{~km}$. As no gene or gene pool specific for A. borisii-regis was found, this taxon represents a hybrid swarm rather than a separate species.

The contact zone of genetic lineages coming from the Balkan and Central-European refugia may serve as another example. Liepelt et al. (2002) treated the whole central Europe as a single hybrid zone between these lineages, forgetting the fact that the Pannonian plane did not harbour any fir populations during the last glacial and the Holocene, and colonization appeared along separate migration trails east and west of this hiatus. This led to unrealistically high estimates of longitudinal cline widths both for seed-dispersed mitochondrial genes $\left(1.72^{\circ} \approx 130 \mathrm{~km}\right)$ and pollen-dispersed chloroplast genes $\left(25.47^{\circ} \approx 1990 \mathrm{~km}\right)$. A re-analysis of the eastern (Carpathian) contact zone by Gömöry et al. (2012a) showed cline width better comparable with $A$. borisii-regis (18 km and $120 \mathrm{~km}$ for seed and pollen dispersal, respectively). Moreover, clines in another anemochorous tree, Fraxinus excelsior L, were comparably wide ( $36 \mathrm{~km}$ and $275 \mathrm{~km}$ for seed and pollen dispersal, respectively) (Gömöry et al. 2012b).

There is a striking difference in the geographical patterns of hybrid zones between wind-dispersed and animal-dispersed species. In both above cases (representing wind-dispersed trees), the contact zone is not necessarily straight but it is always sharp: populations mixed of representatives of both maternal lineages are very scarce and appear just in the closest vicinity of the contact line. This suggests that the colonization fronts in anemochorous species are typically compact, and when they meet, gene flow by seeds across the meeting line is very limited, while a further movement of the colonization front is blocked. In contrast, in zoochorous trees such as beech or oaks, colonization is accomplished by long-distance 
dispersal events, when a few beechnuts or acorns are transported far from the colonization front (usually by birds), buried or lost, and give rise to a new local subpopulation. The outcome of this dispersal strategy is a broad hybrid zone, where pure patches of the either haplotype alternate (Magri et al. 2006). In oaks, the same haplotype is even shared across species (Petit et al. 1997).

\section{Adaptation}

Since Darwin's times, adaptation to a specific niche through natural selection has always been considered the most important mechanism of evolution. In forest trees, taking into account their commercial importance and the role of dominant components of forest ecosystems, the knowledge of adaptation mechanisms is of utterly practical importance.

Industrial pollution, especially sulphur dioxide, has long been the main factor devastating forests in Central Europe. Longauer et al. (2001) compared genetic structures of $P$. abies, A. alba and $F$. sylvatica in pollution-affected stands in subsets of healthy vs. declining trees. The most pronounced effects were found in spruce: paradoxically, declining trees were richer in alleles and more heterozygous than healthy trees. As the declining trees are all dead this time, this means that selection induced by pollution (in this particular case a combination of $\mathrm{SO}_{2}$ and heavy metals) caused depletion of gene pools of the affected stands.

Common-garden experiments may serve as very useful objects for studying adaptation. First, in the case of trees, they typically contain materials collected across a large part of a species' range. Second, all population samples are planted in identical macrosites, i.e. a large part of environmental effects on the assessed traits is eliminated. Gömöry et al. (2015) used the Slovak plot of a Europe-wide beech provenance experiment to identify traits under selection pressure by comparison of differentiation at quantitative traits (approximated by the coefficient of phenotypic differentiation $P_{S T}$ ) and differentiation at neutral markers $\left(F_{S T}\right)$. Local adaptation driven by diversifying selection was found for all vegetative-phenologyrelated traits such as budburst or leaf discoloration date (as indicated by $P_{S T}>F_{S T}$ ), whereas stabilizing selection seems to operate on some physiological traits, e.g. stomatal conductance or transpiration rate $\left(P_{S T}<F_{S T}\right)$.

To get a deeper insight into the issue of adaptation, Sanger sequencing of candidate genes was used in P. abies, F. sylvatica and A. alba; candidate genes showing promising results in earlier studies were chosen; however, in different environmental contexts and under different experimental setups. Again, studies profited from the collection of materials in provenance trials and earlier scoring of growth and phenology, as well as detailed measurements of physiological traits (Romšáková et al. 2012; Krajmerová et al. 2017; Hrivnák et al. 2019; Konôpková et al. 2019). The results were not always consistent among methods ( $F_{S T}$-outlier approach vs. environmental association analysis), which is, however, quite common in this type of studies. In some genes, such as dehydrin-controlling loci, the observation of the signals of climate-driven selection at several single-nucleotide polymorphisms (SNP) was expectable and obvious (Krajmerová et al. 2017). In other cases, the exact mechanisms of the action of different alleles and their protein products showing significant associations with climate or adaptive phenotypic traits still need to be identified.

\section{Perspectives}

The problem of all markers used in the above studies is a limited representativeness; limited in terms of the genome coverage rather than the covering of species' ranges. The numbers of marker loci typically range between 10 and 30 for allozymes and nuclear microsatellites, and with a few exceptions nothing is known about their positions in the genomes. On one hand, the advantage is that a type of markers can be chosen, which is optimal for a respective type of study (e.g, neutral markers for phylogenetic studies, maternally inherited markers to follow migration etc.). On the other hand, generalization and upscaling to a genome-wide scale is hardly possible. The same applies to Sanger sequencing of particular genes or DNA regions. In forest tree genomics, the candidate gene approach has been preferred because of a rapid decay of linkage disequilibrium in tree populations, which makes association studies difficult. The tested candidate genes are usually orthologs or functional equivalents of genes identified in model species (such as Arabidopsis, tobacco, maize or Populus trichocarpa) as responsive to environmental stress or associated with phenotypic traits such as phenology, growth, resistance to drought, heat or diseases, etc. Prior to application in natural populations, they require validation by gene expression or environmental association studies (Neale and Kremer 2011).

The progress of next-generation sequencing (NGS) methods opened much broader possibilities in all fields mentioned in the above sections, as it allowed extending the scale to the whole genome. Of course, resequencing complete genomes is still far from being an operational method of research at the population scale with a justifiable cost-benefit balance (especially not in the main European conifers with genome sizes of $\sim 20 \mathrm{Gbp}$ ). Reduced-representation approaches such as restriction-site associated DNA sequencing (RAD-Seq) allows identification of $10^{4}-10^{5}$ SNPs regularly scattered across the genome at reasonable costs. The Zvolen lab applied double-digest RAD-Seq in evolutionary studies in Alnus glutinosa (L.) Gaertn, F. sylvatica or $P$. abies, whereas phylogeny, genomic architecture in hybrid zones, and climatic and edaphic adaptation are the targeted phenomena. Although travel limitations associated with the 
Covid-19 crisis hampered completing the materials collection and finalizing the results in terms of publication, preliminary results indicate that in all studied species, SNPs of adaptive value can be identified.

Of course, NGS offers much broader possibilities than just reduced-representation sequencing. Reference genomes, indispensable for a plenty of purposes in genetic research, are still available only for a limited number of forest trees. The Zvolen lab participated in sequencing of the Abies alba genome (Mosca et al. 2019). Currently, a consortium of research institutions in Europe (European Reference Genome Atlas; ERGA) was established to generate reference genome assemblies for diverse European species inhabiting aquatic and terrestrial ecosystems, ranging from threatened, endemic and keystone species to species of economic importance. Rapidly decreasing sequencing costs may open an opportunity window for Slovak research teams in NGS application in genome-wide association studies, identification of epigenetic changes, transcriptome analysis and other fields.

Acknowledgments This study is dedicated to two leading personalities of the genetic research of forest trees in Slovakia: professor Ladislav Paule, who has always been (and still is) the spiritus movens behind the population and evolutionary genetics research of trees and wildlife in Zvolen, and Dr. Andrej Kormuták, who was the first to introduce marker studies in that-time Czechoslovakia, and still has remained the gravity point of tree genetics in Nitra.

The review was supported by a grant of the Slovak Grant Agency for Science VEGA 1/0029/20.

Authors' contributions DG wrote the first draft of the review. All authors commented and modified this first draft.

Funding The review was supported by a grant of the Slovak Grant Agency for Science VEGA 1/0029/20.

Data availability Not applicable.

Code availability Not applicable.

\section{Declarations}

Ethics approval Not applicable.

Consent to participate Not applicable.

Consent for publication Not applicable.

Conflicts of interest/competing interests The authors do not perceive any conflict of interests.

\section{References}

Ballian D, Longauer R, Mikić T, Paule L, Kajba D, Gömöry D (2006) Genetic structure of a rare European conifer, Serbian spruce (Picea omorika (Panc.) Purk.). Plant Syst Evol 260:53-63. https://doi.org/ 10.1007/s00606-006-0431-z

Bošel'a M, Popa I, Gömöry D, Longauer R, Tobin B, Kyncl J, Kyncl T, Nechita C, Petráš R, Sidor C, Šebeň V, Büntgen U (2016) Effects of post-glacial phylogeny and genetic diversity on the growth variability and climate sensitivity of European silver fir. J Ecol 104:716724. https://doi.org/10.1111/1365-2745.12561

Coode MJE, Cullen J (1965) Abies Miller. In: Davis PH (ed) Flora of Turkey and East Aegean Islands, vol 1, 1st edn. Edinburgh University Press, Edinburgh, pp 67-70

Feret PP, Bergmann F (1976) Gel electrophoresis of proteins and enzymes. In: Miksche JP (ed) Modern methods in forest genetics. Springer, Berlin, pp 49-78

Gömöry D (1992) Effect of stand origin on the genetic diversity of Norway spruce (Picea abies Karst.) populations. For Ecol Manag 54:215-223. https://doi.org/10.1016/0378-1127(92)90014-z

Gömöry D, Paule L (2010) Reticulate evolution patterns in westernEurasian beeches. Bot Helv 120:63-74. https://doi.org/10.1007/ s00035-010-0068-y

Gömöry D, Schmidtová J (2007) Extent of nuclear genome sharing among white oak species (Quercus L. subgen. Lepidobalanus (End1.) Oerst.) in Slovakia estimated by allozymes. Plant Syst Evol 266:253-264. https://doi.org/10.1007/s00606-007-0535-0

Gömöry D, Yakovlev I, Zhelev P, Jedináková J, Paule L (2001) Genetic differentiation of oak populations within the Quercus robur/ Quercus petraea complex in central and Eastern Europe. Heredity 86:557-563. https://doi.org/10.1046/j.1365-2540.2001.00874.x

Gömöry D, Bruchánik R, Longauer R (2003) Fertility variation and flowering asynchrony in Pinus sylvestris: consequences for the genetic structure in seed orchards. For Ecol Manag 174:117-126. https://doi.org/10.1016/s0378-1127(02)00031-2

Gömöry D, Longauer R, Liepelt S, Ballian D, Brus R, Kraigher H, Parpan VI, Parpan TV, Paule L, Stupar VI, Ziegenhagen B (2004) Variation patterns of mitochondrial DNA of Abies alba Mill. in suture zones of postglacial migration in Europe. Acta Soc Bot Pol 73:203-206. https://doi.org/10.5586/asbp.2004.027

Gömöry D, Paule L, Vyšný J (2007) Patterns of allozyme variation in western-Eurasian beeches. Bot J Linn Soc 154:165-174. https://doi. org/10.1111/j.1095-8339.2007.00666.x

Gömöry D, Paule L, Krajmerová D, Romšáková I, Longauer R (2012a) Admixture of genetic lineages of different glacial origin: a case study of Abies alba Mill. in the Carpathians. Plant Syst Evol 298: 703-712. https://doi.org/10.1007/s00606-011-0580-6

Gömöry D, Paule L, Krajmerová D, Romšáková I, Piecka J (2012b) Gene exchange between postglacial migration streams in Fraxinus excelsior. Silvae Genet 61:18-27. https://doi.org/10.1515/sg-20120003

Gömöry D, Ditmarová L', Hrivnák M, Jamnická G, Kmet’ J, Krajmerová D, Kurjak D (2015) Differentiation in phenological and physiological traits in European beech (Fagus sylvatica L.). Eur J For Res 134: 1075-1085. https://doi.org/10.1007/s10342-015-0910-2

Gömöry D, Paule L, Mačejovský V (2018) Phylogeny of beech in western Eurasia as inferred by approximate Bayesian computation. Acta Soc Bot Pol 87:3582. https://doi.org/10.5586/asbp.3582

Hall RB, Miksche JP, Hansen KM (1976) Nucleic acid extraction, purification, reannealing and hybridization methods. In: Miksche JP (ed) Modern methods in forest genetics. Springer, Berlin, pp 19-48

Hrivnák M, Paule L, Krajmerová D, Kulaç Ș, Șevik H, Turna İ, Tvauri I, Gömöry D (2017) Genetic variation in Tertiary relics: the case of eastern-Mediterranean Abies (Pinaceae). Ecol Evol 7:10018-11030. https://doi.org/10.1002/ece3.3519

Hrivnák M, Krajmerová D, Gömöry D (2019) Lack of signals of selection at candidate loci at a small geographical scale along a steep altitudinal gradient in Norway spruce (Picea abies Karst.). Acta Biol Cracov Bot 61:43-51. https://doi.org/10.24425/abcsb.2019.127740 
König AO (2005) Provenance research: evaluating the spatial pattern of genetic variation. In: Geburek T, Turok J (eds) Conservation and management of forest genetic resources in Europe. Arbora Publishers, Zvolen, pp 275-333

Konôpka J, Varínsky J, Zúbrik M (2013) Lesnícky výskumný ústav Zvolen - 115. výročie organizovaného výskumu na Slovensku. História a súčasnost'. Národné lesnícke centrum - Lesnícky výskumný ústav, Zvolen

Konôpková A, Krajmerová D, Kurjak D, Kmet' J, Pšidová E, Kučerová J, Hrivnák M, Longauer R, Ditmarová L, Gömöry D (2019) Nucleotide polymorphisms associated with climate and physiological traits in silver fir (Abies alba Mill.) provenances. Flora 250:3743. https://doi.org/10.1016/j.flora.2018.11.012

Kormuták A (1981) Isozyme composition of some Abies species. Biologia 36:3-13

Kormuták A (1985) Study on species hybridization within the genus Abies. Acta Dendrobiologica, Bratislava

Kormuták A (1986) Gametophytic incompatibility between Abies cephalonica Loud. and Abies concolor [Gord. et Glend.] Lindl. var. lowiana [Gord. Lemm.]. Biologia 41:895-902

Kormuták A (2004) Crossability relationships between some representatives of the Mediterranean, Northamerican and Asian firs (Abies sp.). Veda, Bratislava

Kormuták A, Benčat' F, Rudin D, Seyedyazdani R (1982) Isoenzyme variation in the 4 Slovakian populations of Abies alba Mill. Biologia 37:433-440

Kormuták A, Vooková B, Gajdošová A, Salaj J (1992) Hybridological relationships between Pinus nigra Arn., Pinus thunbergii Parl. and Pinus tabulaeformis Carriere. Silvae Genet 41:228-234

Kormuták A, Szmidt A, Wang XR (1993) Restriction-fragment-lengthpolymorphism of chloroplast DNAs in some species of fir (Abies sp). Biol Plant 35:113-119. https://doi.org/10.1007/Bf02921132

Kormut’ák A, Vooková B, Ziegenhagen B (2002) Reproductive isolation between Colorado white fir (Abies concolor) and the Mediterranean firs. Biologia 57:527-532

Kormuták A, Vooková B, Ziegenhagen B, Kwon HY, Hong YP (2004) Chloroplast DNA variation in some representatives of the Asian, north American and Mediterranean firs (Abies spp). Silvae Genet 53:99-104. https://doi.org/10.1515/sg-2004-0018

Kormuták A, Ostrolucká M, Vooková B, Pret'ová A, Fecková M (2005) Artificial hybridization of Pinus sylvestris L. and Pinus mugo Turra. Acta Biol Cracov Ser Bot 47:129-134

Kormuták A, Demanková B, Gömöry D (2008a) Spontaneous hybridization between Pinus sylvestris L. and Pinus mugo Turra in Slovakia. Silvae Genet 57:76-82. https://doi.org/10.1515/sg-20080012

Kormuták A, Lee SW, Hong KN, Yang BH, Hong YP (2008b) Crossability relationships between Korean firs Abies koreana, A. nephrolepis and A. holophylla and some other representatives of the genus Abies. Biologia 63:94-99. https://doi.org/10.2478/ s11756-008-0008-0

Kormuták A, Vooková B, Čamek V, Salaj T, Galgóci M, Maňka P, Boleček P, Kuna R, Kobliha J, Lukáčik I, Gömöry D (2013) Artificial hybridization of some Abies species. Plant Syst Evol 299:1175-1184. https://doi.org/10.1007/s00606-013-0787-9

Kormuták A, Galgóci M, Maňka P, Koubová M, Jopčík M, Súkeníková D, Boleček P, Gömöry D (2017) Field-based artificial crossings indicate partial compatibility of reciprocal crosses between Pinus sylvestris and Pinus mugo and unexpected chloroplast DNA inheritance. Tree Genet Genomes 13:68. https://doi.org/10.1007/s11295017-1152-x

Kormuták A, Galgóci M, Súkeníková D, Boleček P, Libantová J (2018) Gömöry D (2018) Maternal inheritance of chloroplast DNA in Pinus mugo Turra: a case study of Pinus mugo $\times$ Pinus sylvestris crossing. Plant Syst Evol 304:71-76. https://doi.org/10.1007/s00606-017$1449-0$
Kormuták A, Galgóci M, Boleček P, Gömöry D, Libantová J (2020) Reinforced evidence on partial compatibility between Pinus sylvestris and Pinus mugo and on maternal inheritance of chloroplast DNA in the Pinus mugo $\times$ Pinus sylvestris cross. Silvae Genet 69: 108-115. https://doi.org/10.2478/sg-2020-0015

Krajmerová D, Paule L, Zhelev P, Voleková M, Eftimov I, Gagov V, Gömöry D (2016) Natural hybridization in eastern-Mediterranean firs: the case of Abies borisii-regis. Plant Biosyst 150:1189-1199. https://doi.org/10.1080/11263504.2015.1011723

Krajmerová D, Hrivnák M, Ditmarová L, Jamnická G, Kmet' J, Kurjak D, Gömöry D (2017) Nucleotide polymorphisms associated with climate, phenology and physiological traits in European beech (Fagus sylvatica L.). New Forest 48:463-477. https://doi.org/10.1007/ s11056-017-9573-9

Langlet O (1971) Two hundred years of genecology. Taxon 20:653-722

Lexer C, Kremer A, Petit RJ (2006) Shared alleles in sympatric oaks: recurrent gene flow is a more parsimonious explanation than ancestral polymorphism. Mol Ecol 15:2007-2012. https://doi.org/10. 1111/j.1365-294x.2006.02896.x

Liepelt S, Bialozyt R, Ziegenhagen B (2002) Wind-dispersed pollen mediates postglacial gene flow among refugia. Proc Natl Acad Sci U S A 99:14590-14594. https://doi.org/10.1073/pnas.212285399

Liepelt S, Cheddadi R, de Beaulieu J-L, Fady B, Gömöry D, Hussendörfer E, Konnert M, Litt T, Longauer R, Terhürne-Berson R, Ziegenhagen B (2009) Biogeographic history of Abies alba Mill. - a synthesis from paleobotanic and genetic data. Rev Palaeobot Palynol 153:139-149. https://doi.org/10.1016/j.revpalbo.2008.07. 007

Longauer R, Gömöry D, Paule L, Karnosky DF, Maňkovská B, MüllerStarck G, Percy K, Szaro R (2001) Selection effects of air pollution to gene pools of Norway spruce, European silver fir and European beech. Environ Pollut 115:405-411. https://doi.org/10.1016/s02697491(01)00230-5

Machanská E, Bajcar V, Longauer R, Gömöry D (2013) Effective population size estimation in seed orchards: a case study of Pinus nigra Arnold and Fraxinus excelsior L./F. angustifolia Vahl. Genetika (Beograd) 45:575-588. https://doi.org/10.2298/gensr1302575m

Magri D, Vendramin GG, Comps B, Dupanloup I, Geburek T, Gömöry D, Latalowa M, Litt T, Paule L, Roure JM, Tantau I, van der Knaap WO, Petit RJ, de Beaulieu J-L (2006) Palaeobotanical and genetic data outline the Quaternary history of European beech populations. New Phytol 171:199-222. https://doi.org/10.1111/j.1469-8137. 2006.01740.x

Maňka P, Kormuták A, Galgóci M, Gömöry D (2015) Genetic status of the putative hybrid swarms of mountain dwarf pine and Scots pine in contact zones of their distribution in Slovakia. Biologia 70:1318 1325. https://doi.org/10.1515/biolog-2015-0153

Matúšová R (1995) Genetic variation in 5 populations of silver fir (Abies alba Mill.) in Slovakia. Biologia 50:53-59

Mosca E, Cruz F, Gómez-Garrido J, Bianco L, Rellstab C, Brodbeck S, Csilléry K, Fady B, Fladung M, Fussi B, Gömöry D, GonzálezMartínez SC, Grivet D, Gut M, Hansen OK, Heer K, Kaya Z, Krutovsky KV, Kersten B, Liepelt S, Opgenoorth L, Sperisen C, Ullrich KK, Vendramin GG, Westergren M, Ziegenhagen B, Alioto T, Gugerli F, Heinze B, Höhn M, Troggio M, Neale DB (2019) A reference genome sequence for the European silver fir (Abies alba Mill.): A community-generated genomic resource. G3-Genes Genom Genet 9:2039-2049. https://doi.org/10.1534/g3.119.400083

Muir G, Schlötterer C (2005) Evidence for shared ancestral polymorphism rather than recurrent gene flow at microsatellite loci differentiating two hybridizing oaks (Quercus spp.). Mol Ecol 14:549-561. https://doi.org/10.1111/j.1365-294x.2004.02418.x

Neale DB, Kremer A (2011) Forest tree genomics: growing resources and applications. Nat Rev Genet 12:111-122. https://doi.org/10.1038/ $\operatorname{nrg} 2931$ 
Paule L, Gömöry D (1992) Genetic processes in seed orchards as illustrated by European larch (Larix decidua Mill.) and Scots pine (Pinus sylvestris L.). In: Korpel' Š (ed) Phytotechnique and forest management in present ecological conditions. Technical University in Zvolen, Zvolen, pp 109-114

Petit RJ, Pineau E, Demesure B, Bacilieri R, Ducousso A, Kremer A (1997) Chloroplast DNA footprints of postglacial recolonization by oaks. Proc Natl Acad Sci U S A 94:9996-10001. https://doi. org/10.1073/pnas.94.18.9996

Ravazzi C (2002) Late Quaternary history of spruce in southern Europe. Rev Palaeobot Palynol 120:131-177. https://doi.org/10.1016/ s0034-6667(01)00149-x

Romšáková I, Foffová E, Kmet' J, Longauer R, Pacalaj M, Gömöry D (2012) Nucleotide polymorphisms related to altitude and physiological traits in contrasting provenances of Norway spruce (Picea abies
[L.] Karst.). Biologia 67:909-916. https://doi.org/10.2478/s11756012-0077-y

Salaj J, Kosová A, Kormuták A, Walles B (1998) Ultrastructural and molecular study of plastid inheritance in Abies alba and some Abies hybrids. Sex Plant Reprod 11:284-291. https://doi.org/10. 1007/s004970050155

Seppälä R (1998) IUFRO: history and role in the 21st century. In: Sassa K (ed) Environmental Forest Science, Forestry Sciences, vol 54. Springer, Dordrecht, pp 1-5

Ziegenhagen B, Schauerte M, Kormuták A, Scholz F (1996) Plastid DNA polymorphism of megagametophytes and pollen in two Abies species. Silvae Genet 45:355-358

Publisher's note Springer Nature remains neutral with regard to jurisdictional claims in published maps and institutional affiliations. 